\title{
Effects of benzoic acid and cadmium toxicity on wheat seedlings
}

\author{
Kavita Yadav ${ }^{1}$, and N.B. Singh ${ }^{1 *}$
}

Benzoic acid (BA) and Cd exhibit cumulative effects on plants due to their accumulation in the soil. The present study reports the effects of BA an allelochemical, $\mathrm{Cd}$ and their combinations on seed germination, seedling growth, biochemical parameters, and response of antioxidant enzymes in Triticum aestivum L. The experiment was conducted in sand supplemented with Hoagland nutrient solution. Benzoic acid was applied at concentrations of $0.5,1.0$, and $1.5 \mathrm{mM}$ with or without $\mathrm{Cd}\left(7 \mathrm{mg} \mathrm{L}^{-1}\right)$ to observe effects of allelochemical and $\mathrm{Cd}$ alone and in combination on wheat. Both stresses exhibited inhibitory effect on growth and metabolism of wheat seedlings. The allelochemical in single and combined treatments with $\mathrm{Cd}$ decreased seedling growth as compared to $\mathrm{Cd}$ stress. The two stresses significantly enhanced malondialdehyde content of wheat seedlings. The activity of other antioxidant enzymes, viz. superoxide dismutase (SOD), catalase (CAT), ascorbate peroxidase (APX), and guaiacol peroxidase (POX) were also recorded. SOD increased in seedlings under the two stresses. CAT more prominently ameliorates the toxic effects of $\mathrm{H}_{2} \mathrm{O}_{2}$ as compared with APX and POX and protected wheat seedlings from oxidative stress. Allelochemical buttressed the toxic effect of $\mathrm{Cd}$ on wheat seedlings.

Key words: Antioxidants, allelopathy, lipid peroxidation, oxidative stress, Triticum aestivum.

\section{INTRODUCTION}

Biotic and abiotic stresses affect normal physiological processes of plants including crops of economic importance. Under natural conditions plants are hardly subjected to a single stress factor, rather a group of factors. Allelopathy is a chemical interaction caused by allelochemicals produced by plants in both natural and agro-ecosystems (Dakshini et al., 1999). Allelochemicals are compounds with low molecular weight that interfere with metabolic processes of plants. Several allelochemicals such as $p$-hydroxybenzoic acid, trans- $p$ coumaric, $c i s$ - $p$-coumaric, syringic, vanillic, trans-ferulic and cis-ferulic acid, and 2,4-dihydroxy-7-methoxy-1,4benzoxazin-3-one (DIMBOA) have been reported from shoot and root of wheat seedling (Wu et al., 2001). Phenolic derivatives of benzoic acid (BA) extracted from soil suppress growth and development of plants (Vaughan and Ord, 1991). Allelochemicals influence a number of physiological processes (Blum, 1995; Inderjit and Duke, 2003; Singh et al., 2010). In addition to allelopathy contamination of soil with heavy metals poses a serious ecological problem all over the world. Cadmium $(\mathrm{Cd})$ is one of the most harmful heavy metals, because it is readily taken up by plant cell (Liu et al., 2007). Cadmium is released into the environment by power stations,

${ }^{1}$ University of Allahabad, Department of Botany, Allahabad-211002, India. *Corresponding author (nbsingh.au@gmail.com).

Received: 8 October 2012.

Accepted: 18 March 2013.

doi:10.4067/S0718-58392013000200013. heating systems, metal industries, Ni-Cd batteries, and phosphate fertilizers (Toppi and Gabbrielli, 1999) as well as from geo-chemical weathering of rocks. It causes morphological, anatomical, and physiological changes in plants including growth inhibition, water imbalance, and reduction in seed germination (Benavides et al., 2005; Mishra et al., 2006). Increased level of malondialdehyde (MDA) and $\mathrm{H}_{2} \mathrm{O}_{2}$ are major indicators of $\mathrm{Cd}$ induced oxidative stress in plants (Dixit et al., 2001). It induces both enzymatic and non-enzymatic antioxidant systems in plants (Iannelli et al., 2002). Low level of reactive oxygen species (ROS) produced in cell organelles is usually enhanced under stress condition. Oxidative stress caused by ROS damages macromolecules such as pigments, proteins, nucleic acids, and lipids (Apel and Hirt, 2004). In order to cope with environmental stress, plants have developed protective antioxidant enzyme systems. Several ROS scavenging enzymes such as superoxide dismutase (SOD), catalase (CAT), ascorbate peroxidase (APX), and guaiacol peroxidase (POX) are induced to buttress plant strength (Gratao et al., 2005). Iannelli et al. (2002) reported increased activity of SOD, APX, and CAT in all parts of Phragmites australis (Cav.) Trin. ex Steud. induced by Cd toxicity. The studies on allelochemicals combined with $\mathrm{Cd}$ are scanty. There are no reports on the effect of allelochemicals with $\mathrm{Cd}$ on plants. The objective of this study was to evaluate the interactive effect of two environmental stresses viz. allelopathy and metal stress on Triticum aestivum L. Emphasis was laid on how established cross-interactions i.e. adaptation or synergism could be applied in the agricultural practice. 


\section{MATERIALS AND METHODS}

\section{Seeds, chemicals, and growth and stress treatments}

Seeds of wheat (Triticum aestivum L.) var. HW2004 were procured from seed agency at Allahabad, India; and the heavy metal $\mathrm{CdCl}_{2} \cdot \mathrm{H}_{2} \mathrm{O}$ (molecular weight 201.32) and benzoic acid (molecular weight 122.12) from LOBA Chemie, Mumbai. Heavy metal $\left(7 \mathrm{mg} \mathrm{L}^{-1}\right)$ and benzoic acid $(1.5 \mathrm{mM})$ were prepared separately in buffer $(\mathrm{pH}$ 7.0). The solutions of graded concentrations of benzoic acid were prepared by adding distilled water in output solution before each experiment.

Seeds were surface sterilized with $0.01 \% \mathrm{HgCl}_{2}$ solution and imbibed in water for $3 \mathrm{~h}$. Seeds were sown in plastic pots (height $10 \mathrm{~cm}$ and diameter $6 \mathrm{~cm}$ ) filled with sterilized sand. The sand was treated with $0.2 \mathrm{~N} \mathrm{H}_{2} \mathrm{SO}_{4}$ to remove organic matter then washed three times with distilled water and sterilized at $170{ }^{\circ} \mathrm{C}$ for $24 \mathrm{~h}$. Sand saturated with Hoagland nutrient solution (Hoagland and Arnon, 1950) served as control and supplemented with $7 \mathrm{mg} \mathrm{L}{ }^{-1} \mathrm{CdCl}_{2}$ for $\mathrm{Cd}$ treatment. Benzoic acid (BA) was applied in pots along with Hoagland solution at concentrations of $0.5,1.0$, and $1.5 \mathrm{mM}$ with and without $\mathrm{Cd}$. Sowing was done at the rate of three seeds per pot. Pots were transferred to a growth chamber (temperature: $28 \pm 2{ }^{\circ} \mathrm{C}$; photoperiod: $18: 6 \mathrm{~h}$; humidity: $61 \pm 5 \%$, and photon flux density: $\left.240 \mu \mathrm{mol} \mathrm{m}^{-2} \mathrm{~s}^{-1}\right)$. Pots were irrigated as and when required. The experiments were performed in triplicate.

Germination started on $2 \mathrm{~d}$ after sowing (DAS). Germination was recorded at intervals of $24 \mathrm{~h}$ till 8 DAS. Thinning was done to one seedling per pot. Growth of $14 \mathrm{~d}$ old seedlings was recorded and first fully expanded leaves were sampled for biochemical analysis. Dry weight (DW) of control and treated seedlings was measured.

\section{Sugar content and pigment and protein contents}

The quantification of total soluble sugars was done following Hedge and Hofreiter (1962). About $0.1 \mathrm{~g}$ fresh leaf tissue was homogenized in $5 \mathrm{~mL}$ of $95 \%$ ethanol. After centrifugation, $1 \mathrm{~mL}$ supernatant was mixed with 4 $\mathrm{mL}$ anthrone reagent and heated on boiling water bath for $10 \mathrm{~min}$. Absorbance was recorded at $620 \mathrm{~nm}$ after cooling. The amount of sugar was determined by the standard curve prepared from glucose.

Chlorophylls and carotenoids from leaves $(10 \mathrm{mg})$ of experimental plants were extracted with $80 \%$ acetone and quantified following the method of Lichtenthaler (1987). Protein content was determined according to the method of Lowry et al. (1951). The amount of protein was calculated with reference to standard curve obtained from bovine serum albumin.

\section{Lipid peroxidation}

Lipid peroxidation was measured as the amount of malondialdehyde (MDA) determined by thiobarbituric acid reactive substance (TBRS) as described by Heath and Packer (1968). Fresh leaf $(0.2 \mathrm{~g})$ was ground in 0.1 $\mathrm{w} / \mathrm{v}$ trichloroacetic acid (TCA) and centrifuged at 10000 $\mathrm{g}$ for $10 \mathrm{~min}$. One milliliter of supernatant was mixed with $4 \mathrm{~mL}$ of $0.5 \%$ thiobarbituric acid. The mixture was heated at $95{ }^{\circ} \mathrm{C}$ for $30 \mathrm{~min}$ and it was again centrifuged after cooling. The absorbance of the supernatant was recorded at $532 \mathrm{~nm}$ and corrected by subtracting the non-specific absorbance at $600 \mathrm{~nm}$. The MDA concentration was calculated using the extinction coefficient of $155 \mathrm{mM}^{-1}$ $\mathrm{cm}^{-1}$ and expressed as $\mathrm{n} \mathrm{mol} \mathrm{g}{ }^{-1} \mathrm{FW}$.

\section{Extraction and assay of antioxidant enzymes}

The fresh leaves $(0.25 \mathrm{~g})$ were homogenized with 0.1 $\mathrm{M}$ sodium phosphate buffer containing $1 \%$ polyvinyl pyrrolidone ( $\mathrm{pH} 7.00)$ in a pre-cooled mortar and pestle. The extract was centrifuged at $4{ }^{\circ} \mathrm{C}$ at $15000 \mathrm{~g}$ for 30 min in cooling centrifuge (Remi instruments C 24). The supernatant was used for the assay of superoxide dismutase (SOD), catalase (CAT), ascorbate peroxidase (APX), and guaiacol peroxidase (POX).

\section{Assay of superoxide dismutase and assay of catalase}

The superoxide dismutase (EC 1.15.1.1) was estimated by the nitro blue tetrazolium (NBT) photochemical assay according to the method of Beyer and Fridovich (1987). Reaction mixture (4 mL) consisted of $20 \mathrm{mM}$ methionine, $0.15 \mathrm{mM}$ ethylene diamine-tetra acetic acid (EDTA), 0.12 $\mathrm{mM}$ NBT, $0.5 \mathrm{~mL}$ supernatant. Test tubes were exposed to fluorescent lamp for $30 \mathrm{~min}$ and identical unilluminated assay mixture served as blank. One unit of enzyme was measured as the amount of enzyme which caused 50\% inhibition of NBT reduction.

Catalase activity (EC1.11.1.6) was assayed following Cakmak and Marschner (1992). Assay mixture (2 mL) contained $25 \mathrm{mM}$ potassium phosphate buffer ( $\mathrm{pH} 7.0$ ), $10 \mathrm{mM} \mathrm{H}_{2} \mathrm{O}_{2}$ and $0.5 \mathrm{~mL}$ enzyme extract. The rate of $\mathrm{H}_{2} \mathrm{O}_{2}$ decomposition for $1 \mathrm{~min}$ was monitored at $240 \mathrm{~nm}$ and calculated using extinction coefficient of $39.4 \mathrm{mM}^{-1} \mathrm{~cm}^{-1}$ and expressed as enzyme unit $\mathrm{g}^{-1} \mathrm{FW}$. One unit of catalase was determined as the amount of enzyme required to oxidize $1 \mu \mathrm{M} \mathrm{H}_{2} \mathrm{O}_{2} \min ^{-1}$.

\section{Assay of ascorbate peroxidase and assay of guaiacol peroxidase}

Ascorbate peroxidase (EC1.11.1.11) was assayed following Nakano and Asada (1981). Assay mixture (2 $\mathrm{mL}$ ) contained $25 \mathrm{mM}$ potassium phosphate buffer $(\mathrm{pH}$ 7.0), $0.1 \mathrm{mM}$ EDTA, $0.25 \mathrm{mM}$ ascorbate, $1.0 \mathrm{mM} \mathrm{H}_{2} \mathrm{O}_{2}$ and $0.2 \mathrm{~mL}$ enzyme extract. $\mathrm{H}_{2} \mathrm{O}_{2}$ was the last component to be added. The absorbance was recorded for $1 \mathrm{~min}$ at $290 \mathrm{~nm}$ (extinction coefficient of $2.8 \mathrm{mM}^{-1} \mathrm{~cm}^{-1}$ ). Enzyme specific activity was measured as enzyme unit $\mathrm{g}^{-1} \mathrm{FW}$ as the amount of enzyme required to oxidize $1 \mu \mathrm{M} \mathrm{H}_{2} \mathrm{O}_{2}$ min $^{-1}$.

Guaiacol peroxidase (EC 1.11.1.7) was assayed following Hemeda and Klein (1990). The reaction 
mixture ( $2 \mathrm{~mL}$ ) consisted of $25 \mathrm{mM}$ phosphate buffer $(\mathrm{pH}$ 7.0), $0.1 \mathrm{mM}$ EDTA, $0.05 \%$ guaiacol, $1.0 \mathrm{mM} \mathrm{H}_{2} \mathrm{O}_{2}$ and $0.2 \mathrm{~mL}$ of enzyme extract. The increase in absorbance due to oxidation of guaiacol was monitored at $470 \mathrm{~nm}$. The enzyme activity was measured using extinction coefficient of $26.6 \mathrm{mM}^{-1} \mathrm{~cm}^{-1}$ and expressed as enzyme unit $\mathrm{g}^{-1} \mathrm{FW}$.

\section{Statistical analysis}

Treatments were arranged in a randomized block design with three replicates. Standard errors of means were calculated. In addition, ANOVA was carried out for all the data generated from this experiment, employing one way ANOVA test using GPIS software 3.0 (GRAPHPAD, California, USA).

\section{RESULTS AND DISCUSSION}

\section{Seed germination, seedling growth and sugar contents}

Seed germination decreased significantly $(\mathrm{p}<0.05)$ in dose dependent manner by application of BA in dose dependent manner. Maximum $37.5 \%$ reduction in germination was recorded at highest concentration of BA. Cadmium exhibited adverse effect in single treatment and in combinations with BA. Allelopathic stress caused by BA suppressed seedling height to $14.6 \%$ as compared with control. However, no alteration was observed under combined stress when compared with single stress. Dry weight (DW) of seedlings significantly declined under the influence of both stresses. Cadmium decreased DW and proved to be more toxic as compared to BA stress. Combination of two stresses further decreased DW. Sugar content significantly increased under stress. The increase of sugar was higher under allelochemical stress as compared to metal stress. BA at highest concentration caused maximum increase (3.65 times) in sugar content over control. BA+Cd combinations elevated sugar content as compared to single treatments of BA and $\mathrm{Cd}$. Seedlings treated with $\mathrm{B}_{3}+\mathrm{Cd}$ treatment exhibited maximum 5.94 times increase in sugar content as compared with control (Table 1).

Under natural conditions plants are rarely affected by

Table 1. Effects of benzoic acid and $\mathrm{Cd}$ on seed germination, seedling height, dry weight, and sugar content of Triticum aestivum.

\begin{tabular}{lcccc}
\hline Treatments & $\begin{array}{c}\text { Seed } \\
\text { germination }\end{array}$ & $\begin{array}{c}\text { Seedling } \\
\text { height }\end{array}$ & $\begin{array}{c}\text { Dry } \\
\text { weight }\end{array}$ & $\begin{array}{c}\text { Sugar } \\
\text { content }\end{array}$ \\
\hline & $\%$ & $\mathrm{~cm}$ & mg plant $^{-1}$ & $\mathrm{mg} \mathrm{g}^{-1} \mathrm{FW}$ \\
$\mathrm{C}$ & $80.00 \pm 3.85$ & $3.63 \pm 0.29$ & $36.83 \pm 0.44$ & $14.32 \pm 3.06$ \\
$\mathrm{Cd}$ & $61.55 \pm 2.19^{\mathrm{a}}$ & $3.26 \pm 0.35$ & $18.33 \pm 1.59^{\mathrm{c}}$ & $24.64 \pm 1.75$ \\
$\mathrm{~B}_{1}$ & $56.88 \pm 1.93^{\mathrm{b}}$ & $3.40 \pm 0.56$ & $24.83 \pm 0.72^{\mathrm{c}}$ & $25.83 \pm 6.92$ \\
$\mathrm{~B}_{2}$ & $54.11 \pm 0.48^{\mathrm{c}}$ & $3.26 \pm 0.03$ & $23.66 \pm 1.45^{\mathrm{c}}$ & $44.03 \pm 2.19^{\mathrm{c}}$ \\
$\mathrm{B}_{3}$ & $50.00 \pm 1.92^{\mathrm{c}}$ & $3.10 \pm 0.15$ & $22.83 \pm 1.01^{\mathrm{c}}$ & $52.35 \pm 0.89^{\mathrm{c \# x}}$ \\
$\mathrm{B}^{1}+\mathrm{Cd}$ & $57.78 \pm 3.93^{\mathrm{b}}$ & $3.03 \pm 0.08$ & $24.83 \pm 0.88^{\mathrm{c}}$ & $54.36 \pm 2.05^{\mathrm{c \# x}}$ \\
$\mathrm{B}_{2}+\mathrm{Cd}$ & $57.33 \pm 3.00^{\mathrm{b}}$ & $3.00 \pm 0.11$ & $21.83 \pm 0.72^{\mathrm{c}}$ & $58.79 \pm 2.89^{\mathrm{c \# x}}$ \\
$\mathrm{B}_{3}+\mathrm{Cd}$ & $47.78 \pm 4.84^{\mathrm{c}}$ & $2.90 \pm 0.10$ & $20.66 \pm 1.16^{\mathrm{c}}$ & $85.09 \pm 1.20^{\mathrm{c \# xyz} \mathrm{s}}$ \\
\hline
\end{tabular}

Data are mean of three replicates \pm standard error of the mean (SEM).

${ }^{\mathrm{a} P} P<0.05,{ }^{\mathrm{b}} P<0.01,{ }^{\mathrm{c}} P<0.001$ versus $\mathrm{C},{ }^{\#} P<0.001$ versus $\mathrm{Cd},{ }^{\mathrm{x}} P<0.001$ versus $\mathrm{B}_{1},{ }^{\mathrm{y}} P<0.001$ versus $\mathrm{B}_{2},{ }^{\mathrm{z}} P<0.001$ versus $\mathrm{B}_{3},{ }^{\mathrm{*}} P<0.001$ versus $\mathrm{B}_{1}+\mathrm{Cd},{ }^{\$} P<0.001$ versus $\mathrm{B}_{2}+\mathrm{Cd}$.

FW: fresh weight, C: control, $\mathrm{Cd}: 7 \mathrm{mg} \mathrm{L}^{-1}, \mathrm{~B}_{1}, \mathrm{~B}_{2}$, and $\mathrm{B}_{3}: 0.5,1.0$, and $1.5 \mathrm{mM}$ benzoic acid, respectively. a single stress, rather subjected to combination of various environmental stresses. The present study was aimed to explore the impact of two important environmental stresses on plants and efficiency of defense system to mitigate the effect. Seed germination and seedling growth decreased with increase in concentration of allelochemical applied with and without $\mathrm{Cd}$. BA reduced seed germination and seedling growth as reported by Yu and Matusi (1997). Cadmium exhibited toxic impact on germination and seedling growth (Rascio et al., 1993; Asgharipour et al., 2011). Variation of plant growth at germination and seedling stage under stress is often regarded as an important index to investigate plant tolerance to stress. Cadmium is known to inhibit cell growth by formation of stronger cross-binding between the pectin molecules in the cell wall and by decrease in size of intercellular spaces (Prasad, 1995). Wheat seedlings DW decreased under stress and more prominently in metal stress. Decrease in DW corresponded to level of chlorophyll content in respective treatments (Buttery and Buzzell, 1977; Dube et al., 2002). Photosynthesis is proportional to chlorophyll content which decreased plant growth. In combined treatments, inhibition of germination rates, seedling growth and DW revealed that BA and Cd worked antagonistically because reduction of all the above parameters was lesser than sum of inhibition caused by BA and Cd separately. The stimulatory effect of BA and $\mathrm{Cd}$ on sugar content was recorded. Stress conditions which cause accumulation of ROS, directly or indirectly, are associated with soluble sugar accumulation, which has generally been associated to be an adaptive response to the stress situation (Roitsch, 1999). Asgharipour et al. (2011) found that $\mathrm{Cd}$ increased the sugar content of wheat seedlings. The elevated sugar level observed in stressed seedlings can be explained by less utilization of sugar for growth of seedlings subjected to stress (Asgharipour et al., 2011). Soluble sugars contribute to defense and act as signal molecule that benefits the plant. It sense and control photosynthetic activity and ROS balance (Couée et al., 2006).

\section{Pigment and protein contents}

Allelochemical and Cd did not significantly influence total pigment content of wheat seedlings. However chlorophyll decreased significantly under combined treatments. Maximum $29.32 \%$ reduction in total chlorophyll was observed in $\mathrm{B}_{3}+\mathrm{Cd}$ treatment as compared with control. BA in highest concentrations decreased carotenoid content. All combinations decreased carotenoid content when compared with single stress treatment. $\mathrm{B}_{3}+\mathrm{Cd}$ exhibited most inhibitory effect on carotenoid content. Protein content of wheat seedlings decreased significantly under $\mathrm{Cd}$ stress. BA at highest concentration $(1.5 \mathrm{mM})$ caused maximum $15.03 \%$ reduction of protein content as compared with control. Cadmium with higher concentrations of BA decreased amount of protein (Table 2). 
Table 2. Effects of benzoic acid and Cd on pigment and protein contents of Triticum aestivum.

\begin{tabular}{|c|c|c|c|c|c|}
\hline Treatments & Chlorophyll a & Chlorophyll b & Total chlorophyll & Carotenoid & Protein \\
\hline & & & $-\mathrm{mg} \mathrm{g}^{-1} \mathrm{FW}$ & & \\
\hline $\mathrm{C}$ & $9.68 \pm 0.272$ & $3.61 \pm 0.052$ & $13.30 \pm 0.324$ & $23.91 \pm 3.24$ & $15.23 \pm 0.62$ \\
\hline $\mathrm{Cd}$ & $9.04 \pm 0.353$ & $3.52 \pm 0.081$ & $12.56 \pm 0.434$ & $23.13 \pm 1.36$ & $13.11 \pm 0.49^{\mathrm{a}}$ \\
\hline $\mathrm{B}_{1}$ & $9.04 \pm 0.336$ & $3.47 \pm 0.112$ & $12.52 \pm 0.449$ & $16.67 \pm 1.05^{\mathrm{b}}$ & $14.07 \pm 0.25$ \\
\hline $\mathrm{B}_{2}$ & $8.83 \pm 0.186$ & $3.40 \pm 0.040$ & $12.24 \pm 0.226$ & $16.36 \pm 1.40^{\mathrm{b}}$ & $14.3 \pm 0.72$ \\
\hline $\mathrm{B}_{3}$ & $8.90 \pm 0.029$ & $3.35 \pm 0.227$ & $12.26 \pm 0.249$ & $14.09 \pm 1.92^{\mathrm{c}}$ & $12.94 \pm 0.39^{\mathrm{a}}$ \\
\hline $\mathrm{B}_{1}+\mathrm{Cd}$ & $8.43 \pm 0.017^{\mathrm{a}}$ & $3.39 \pm 0.302$ & $11.83 \pm 0.310$ & $13.95 \pm 0.78^{c}$ & $13.26 \pm 0.45$ \\
\hline $\mathrm{B}_{2}+\mathrm{Cd}$ & $7.99 \pm 0.035^{\mathrm{c}}$ & $3.08 \pm 0.049$ & $11.07 \pm 0.085^{\mathrm{b}}$ & $13.46 \pm 1.52^{\mathrm{c}}$ & $13.21 \pm 0.16^{\mathrm{a}}$ \\
\hline $\mathrm{B}_{3}+\mathrm{Cd}$ & $6.85 \pm 0.067^{\mathrm{c \# xyz}}$ & $2.20 \pm 0.409^{b}$ & $8.87 \pm 0.471^{\mathrm{c \# xyz}}$ & $10.37 \pm 1.49^{\mathrm{c \#}}$ & $12.94 \pm 0.50^{\mathrm{a}}$ \\
\hline
\end{tabular}

Data are mean of three replicates \pm standard error of the mean (SEM).

${ }^{\mathrm{a}} P<0.05,{ }^{\mathrm{b}} P<0.01,{ }^{\mathrm{c}} P<0.001$ versus $\mathrm{C},{ }^{\#} P<0.001$ versus $\mathrm{Cd},{ }^{\mathrm{x}} P<0.001$ versus $\mathrm{B}_{1},{ }^{\mathrm{y}} P<0.001$ versus $\mathrm{B}_{2},{ }^{\mathrm{z}} P<0.001$ versus $\mathrm{B}_{3},{ }^{*} P<0.001$ versus $\mathrm{B}_{1}+\mathrm{Cd}$.

FW: fresh weight, $\mathrm{C}$ : control, $\mathrm{Cd}: 7 \mathrm{mg} \mathrm{L}^{-1}, \mathrm{~B}_{1}, \mathrm{~B}_{2}$, and $\mathrm{B}_{3}: 0.5,1.0$, and $1.5 \mathrm{mM}$ benzoic acid, respectively.

Allelochemical and metal decreased chlorophyll contents which may be due to inhibition of biosynthesis of chlorophyll (Baziramakenga et al., 1994). In the present study BA inhibited chlorophyll synthesis which was evident from decreased biosynthesis of chlorophyll a which influenced total chlorophyll. Cadmium also reduced chlorophyll content. Oncel et al. (2000) found that $\mathrm{Cd}$ reduced chlorophyll in wheat seedlings. Cadmium severely inhibits plant growth and even causes plant death by disturbing the uptake of nutrients and inhibiting photosynthesis via degradation of chlorophyll (Zhang et al., 2007). Carotenoid was more sensitive towards stress as compared with chlorophyll in respective treatments. Single and combined stress treatment exhibited negative impact on carotenoid content of wheat seedling (Ünyayar et al., 2005; Mishra and Agrawal, 2006). The decrease in carotenoid content is harmful to chlorophyll because carotenoid protects chlorophyll from photooxidative destruction (Middleton and Teramura, 1993). Both allelochemical and metal stresses reduced protein content. BA (Baziramakenga et al., 1994) and Cd (Gupta et al., 2003) caused reduction of protein content. Both stresses are known to produce ROS (Zhang et al., 2010; Nahakpam and Shah, 2010) which caused modification/degradation of proteins (Pacifice and Davies, 1990). The inhibition of chlorophyll biosynthesis by BA and $\mathrm{Cd}$ treatments influenced photosynthesis and ultimately decreased protein contents. The counteractive effect of BA and $\mathrm{Cd}$ was observed in combinations as the percentage decrease of protein content was lesser than sum of decrease caused by both stress.

\section{Lipid peroxidation and antioxidant enzymes activity} Lipid peroxidation (LP) measured in terms of MDA content exhibited high reactivity with thiobarbituric acid. The level of MDA increased under allelochemical stresses with maximum $42.72 \%$ increase in $\mathrm{B}_{3}$ treatment. $\mathrm{BA}+\mathrm{Cd}$ stimulated LP as compared to single stress. Application of BA with Cd synergistically increased MDA content in graded manner in comparison to sum of increase caused by BA and Cd (Table 3 ).

Increased level of MDA in response to metal and allelochemical stress indicated the oxidative stress in wheat seedling through the formation of free radicals. MDA accumulation was more prominent in BA. It reveals that $\mathrm{BA}$ is more toxic than $\mathrm{Cd}$. Cadmium caused oxidative stress resulting into membrane damage (Sharma et al., 2004) by stimulating LP in Cd stressed seedlings as reported by several authors (Finkemeier et al., 2003; Metwally et al., 2003). BA synergized the impact of Cd by accelerating LP. The elevation of LP was more as compared to sum of increase caused by individual stress in respective treatments. Lipid molecules are very sensitive to oxidation by ROS generated under BA stress (Baziramakenga et al., 1995). Lipid peroxidation resulted in the formation of lipid radicals (lipid peroxides). Thus elevated level of lipid peroxides is generally accepted as an indicator of severe oxidative stress (El-Tayeb, 2005).

Table 3. Effects of benzoic acid and cadmium on lipid peroxidation and antioxidant enzymes activity of Triticum aestivum.

\begin{tabular}{|c|c|c|c|c|c|}
\hline Treatments & Lipid peroxidation & Superoxide dismutase & Catalase & Ascorbate peroxidase & Guaiacol peroxidase \\
\hline & $\mathrm{n} \mathrm{mol} \mathrm{g}^{-1} \mathrm{FW}$ & & - & & \\
\hline $\mathrm{C}$ & $48.38 \pm 0.18$ & $32.33 \pm 1.67$ & $0.27 \pm 0.039$ & $0.32 \pm 0.10$ & $0.83 \pm 0.14$ \\
\hline $\mathrm{Cd}$ & $50.36 \pm 0.68$ & $38.34 \pm 0.97$ & $0.30 \pm 0.019$ & $0.67 \pm 0.14$ & $0.67 \pm 0.07$ \\
\hline $\mathrm{B}_{1}$ & $50.87 \pm 0.52$ & $48.59 \pm 2.24^{b}$ & $0.25 \pm 0.009$ & $1.17 \pm 0.26$ & $0.90 \pm 0.09$ \\
\hline $\mathrm{B}_{2}$ & $57.35 \pm 1.08^{\mathrm{c} \# \mathrm{x}}$ & $51.90 \pm 4.42^{\mathrm{c}}$ & $0.27 \pm 0.011$ & $2.49 \pm 0.32$ & $1.02 \pm 0.02$ \\
\hline $\mathrm{B}_{3}$ & $62.58 \pm 0.37^{c \# x y}$ & $53.08 \pm 0.55^{\mathrm{c}}$ & $0.42 \pm 0.068$ & $1.89 \pm 0.26$ & $1.07 \pm 0.01$ \\
\hline $\mathrm{B}_{1}+\mathrm{Cd}$ & $65.15 \pm 0.22^{\mathrm{c \# xy}}$ & $61.77 \pm 1.11^{\mathrm{c \#}}$ & $0.59 \pm 0.029^{\mathrm{c} \# \mathrm{xy}}$ & $1.32 \pm 0.02$ & $1.38 \pm 0.01^{\mathrm{b} \#}$ \\
\hline $\mathrm{B}_{2}+\mathrm{Cd}$ & $66.48 \pm 0.50^{\mathrm{c} \# x y}$ & $64.96 \pm 1.75^{\mathrm{c} \#}$ & $0.64 \pm 0.019^{\mathrm{c} \# \mathrm{xy}}$ & $2.28 \pm 0.94$ & $1.75 \pm 0.05^{\mathrm{c \# xy}}$ \\
\hline $\mathrm{B}_{3}+\mathrm{Cd}$ & $69.05 \pm 0.33^{\mathrm{c \# xyz}}$ & $70.15 \pm 1.69^{\mathrm{ckxyz}}$ & $0.69 \pm 0.048^{\mathrm{c} \# \mathrm{xy}}$ & $3.42 \pm 0.53^{\mathrm{b}}$ & $1.84 \pm 0.15^{\mathrm{c \# xyz}}$ \\
\hline
\end{tabular}

Data are mean of three replicates \pm standard error of the mean (SEM).

${ }^{\mathrm{b}} P<0.01,{ }^{\mathrm{c}} P<0.001$ versus $\mathrm{C},{ }^{\sharp} P<0.001$ versus $\mathrm{Cd},{ }^{\mathrm{x}} P<0.001$ versus $\mathrm{B}_{1},{ }^{\mathrm{y}} P<0.001$ versus $\mathrm{B}_{2},{ }^{\mathrm{r}} P<0.001$ versus $\mathrm{B}_{3}$.

$\mathrm{C}$ : control, $\mathrm{Cd}: 7 \mathrm{mg} \mathrm{L}^{-1}, \mathrm{~B}_{1}, \mathrm{~B}_{2}$, and $\mathrm{B}_{3}: 0.5,1.0$, and $1.5 \mathrm{mM}$ benzoic acid, respectively. 
We quantified the activity of antioxidant enzymes viz. SOD, CAT, APX, and POX to compare the oxidative damage caused by metal and allelochemical stresses on wheat seedlings. The activity of SOD increased significantly $(\mathrm{p}<0.05)$ in response to allelochemical stress. Elevation of SOD activity was more prominent in $\mathrm{BA}$ as compared to $\mathrm{Cd}$ stress with maximum 1.64 fold increase in $\mathrm{B}_{3}$ treatment. Seedlings in Cd treatment showed no effect on SOD activity. The seedlings under combined stress exhibited graded increase in SOD activity and comparatively higher when compared with sum of BA and Cd stress. BA exhibited no effect on CAT activity as compared to control. When compared to single stress, BA, and Cd in combinations stimulated CAT activity. Significant elevation of APX activity was evident in higher concentrations of BA while POX activity did not increase significantly. As compared to single treatment, higher level of POX was recorded in the seedlings treated with combination of allelochemical and Cd. Single stress exhibited no influence on POX activity, however in combined treatments it increased significantly in dose dependent manner with maximum $121.68 \%$ increase in $\mathrm{B}_{3}+\mathrm{Cd}$ treatment (Table 3).

The two stresses induced antioxidant enzyme in wheat seedlings. Lipid peroxidation corresponded to SOD activity. A significant $(\mathrm{p}<0.05)$ elevation of SOD activity in seedlings subjected to BA+Cd stress suggested synergistic effect. Our results with increased activity of SOD and CAT under different allelochemical stress in wheat seedlings are in agreement with studies on several crops viz. Lycopersicon esculentum L. (Macias et al., 2002), Cucumis sativus L. (RomeroRomero et al., 2005), Brassica campestris L. (Oracz et al., 2007) and Zea mays L. (Singh et al., 2009). Cd toxicity is reported to enhance SOD activity in leaves and roots of Phragmites australis (Iannelli et al., 2002). Elevation in SOD activity as recorded in $\mathrm{BA}+\mathrm{Cd}$ treatments leads to the accumulation of $\mathrm{H}_{2} \mathrm{O}_{2}$. It is quite pertinent that the net oxidative stress is the result of overall alteration in the ratio of $\mathrm{O}_{2}{ }^{-}$scavenging enzyme (SOD) and $\mathrm{H}_{2} \mathrm{O}_{2}$ scavenging enzymes (CAT, APX, and POX) (Kanazawa et al., 2000; Shah et al., 2001). APX present in chloroplasts involves in ascorbate glutathione cycle while POX present in cytoplasm binds with cell wall. It seems that increased and decreased activity of CAT in $\mathrm{Cd}$ and $\mathrm{B}_{1}$ treatments respectively compensated by altered activity of other two $\mathrm{H}_{2} \mathrm{O}_{2}$ scavenging enzymes viz. APX and POX in respective treatments. The allelochemical with $\mathrm{Cd}$ played protective role by stimulating the activity of antioxidant enzymes. The stimulation of CAT activity in allelochemical stress has been shown in earlier studies (Batish et al., 2006; Singh et al., 2010). Ferulic acid and BA are known to elevate CAT activity in maize seedling (Devi and Prasad, 1996) and cucumber cotyledons (Maffei et al., 1999) respectively. Our results are in agreement with these findings. $\mathrm{Cd}$ toxicity reduces activity of $\mathrm{H}_{2} \mathrm{O}_{2}$ scavengers causing $\mathrm{H}_{2} \mathrm{O}_{2}$ accumulation in plants (Hatata and Abdel-Aal, 2008). Allelochemical with Cd increased APX activity over Cd treatment. Ünyayar et al. (2005) also reported that SOD and APX activity increased in response to combined stress (drought $+\mathrm{Cd}$ ) as compared to single stress. Our results reveal better performance of antioxidant enzymes under BA stress as compared to $\mathrm{Cd}$ and also in combination of $\mathrm{BA}+\mathrm{Cd}$ when compared with single stress. Single stress has no influence on POX activity, however in combined treatment POX activity increased significantly. Allelochemical and metal work synergistically and increase antioxidant enzymes activity under combined treatments as compared to sum of elevation caused by single stress.

\section{CONCLUSIONS}

The present investigation showed that $\mathrm{Cd}$ toxicity creates a stressed condition in wheat plants that required protection of defense system. Seed germination, seedling growth, and biochemical parameters varied with benzoic acid, $\mathrm{Cd}$, and combined treatments. Under combined treatments, toxicity reduced antagonistically as compared to sum of toxicity caused by $\mathrm{Cd}$ and allelochemical. Allelochemical appear to mitigate the effect of $\mathrm{Cd}$ and buttress antioxidant defense system in presence of $\mathrm{Cd}$. An involvement of cellular antioxidant defense system against oxidative stress broadens the understanding of impact of two different stresses on wheat plants. The cross-adaptation or synergism can be induced. This study reveals new possibilities for deliberate and predictable approach for induced adaptation in crop plants.

\section{ACKNOWLEDGEMENTS}

The authors are thankful to the UGC, New Delhi and University of Allahabad, Allahabad, India, for providing financial assistance to Kavita Yadav.

\section{LITERATURE CITED}

Apel, K., and H. Hirt. 2004. Reactive oxygen species: metabolism, oxidative stress and signal transduction. Annual Review of Plant Biology 55:373-399.

Asgharipour, M.R., M. Khatamipour, and M. Razavi-Omrani. 2011. Phytotoxicity of cadmium on seed germination, early growth, proline and carbohydrate content in two wheat varieties. Advances in Environmental Biology 5:559-565.

Batish, D.R., H.P. Singh, N. Setia, S. Kaur, and R.K. Kohli. 2006 2-Benzoxazolinone (BOA) induced oxidadive stress, lipid peroxidation and changes in some antioxidant enzyme activities in mung bean (Phaseolus aureus). Plant Physiology and Biochemistry 44:819-827.

Baziramakenga, R., G.D. Leroux, and R.R. Simard. 1995. Effects of benzoic and cinnamic acids on membrane permeability of soybean roots. Journal of Chemical Ecology 21:1271-1285.

Baziramakenga, R., R.R. Simard, and G.D. Leroux. 1994. Effects of benzoic and cinnamic acid on growth, chlorophyll and mineral contents of soybean. Journal of Chemical Ecology 20:2821-2833. 
Benavides, M.P., S.M. Gallego, and M.L. Tomaro. 2005. Cadmium toxicity in plants. Brazilian Journal of Plant Physiology 17:21-34.

Beyer, W.F., and I. Fridovich. 1987. Assaying for superoxide dismutase activity: some large consequences of minor changes in conditions. Analytical Biochemistry 161:559-566.

Blum, U. 1995. The value of model plant-microbe-soil systems for understanding processes associated with allelopathic interaction: One example. p. 127-131. In Inderjit, K.M.M. Dakshini, and F.A. Einhellig (eds.) Allelopathy: Organisms, processes and application. ACS Symposium Series 582. American Chemical Society, Washington, DC., USA.

Buttery, B.R., and R.I. Buzzell. 1977. The relationship between chlorophyll content and rate of photosynthesis in soybeans. Canadian Journal of Plant Science 57:1-5.

Cakmak, I., and H. Marschner. 1992. Magnesium deficiency and high light intensity enhance activities of superoxide dismutase, ascorbate peroxidase and glutathione reductase in bean leaves. Plant Physiology 98:1222-1227.

Couée, I., C. Sulmon, G. Gouesbet, and A.E. Amrani. 2006. Involvement of soluble sugar in reactive oxygen species balance and responses to oxidative stress in plants. Journal of Experimental Botany 57:449-459.

Dakshini, K.M.M., C.L. Foy, and Inderjit. 1999. Allelopathy: one component in a multifaceted approach to ecology. p. 3-14. In Dakshini, K.M.M., C.L. Foy, and Inderjit (eds.) Principles and procedures in plant ecology: Allelochemical interactions. CRC Press, Boca Raton, Florida, USA.

Devi, S.R., and M.N.V. Prasad. 1996. Ferulic acid mediated changes in oxidative enzymes of maize seedlings: implications in growth. Biologia Plantarum 38:387-395.

Dixit, V., V. Pandey, and R. Shyam. 2001. Differential oxidative responses to cadmium in root and leaves of pea (Pisum sativum $\mathrm{L}$. cv. Azad). Journal of Experimental Botany 52:1101-1109.

Dube, B.K., P. Sinha, and C. Chatterjee. 2002. Changes in spinach metabolism by excess cadmium. Nature Environment and Pollution Technology 1:225-229.

El-Tayeb, M.A. 2005. Response of barley grains to the interactive effect of salinity and salicylic acid. Plant Growth Regulation 45:215-224

Finkemeier, I., C. Kluge, A. Metwally, M. Georgi, N. Grotjohann, and K.J. Dietz. 2003. Alteration in Cd-induced gene expression under nitrogen deficiency in Hordeum vulgare. Plant Cell Environment 26:821-833.

Gratao, P.L., A. Polle, P.J. Lea, and R.A. Azevedo. 2005. Making the life of heavy metal-stressed plants a little easier. Functional Plant Biology 32:481-494.

Gupta, D.K., U.N. Rai, A. Singh, and M. Inouhe. 2003. Cadmium accumulation and toxicity in Cicer arietinum L. Pollution Research 22:457-463.

Hatata, M.M., and E.A. Abdel-Aal. 2008. Oxidative stress and antioxidant defense mechanisms in response to cadmium treatments. American-Eurasian Journal of Agriculture and Environmental Sciences 4:655-669.

Heath, R.L., and L. Packer. 1968. Photoperoxidation in isolated chloroplasts. 1. Kinetics and stoichiometry of fatty acid peroxidation. Archives of Biochemistry and Biophysics 125:189198.

Hedge, J.E., and B.T. Hofreiter. 1962. Estimation of carbohydrate. p. 17-22. In Whistler, R.L., and J.N. Be Miller (eds.) Methods in carbohydrate chemistry. Academic Press, New York, USA.

Hemeda, H.M., and B.P. Klein. 1990. Effects of naturally occurring antioxidants on peroxidase activity of vegetable extracts. Journal of Food Science 55:184-185.

Hoagland, D.R., and D.I. Arnon. 1950. The water-culture method for growing plants without soil. California Agricultural Experiment Station Circular 347. College of Agriculture, University of California, Berkeley, California, USA.

Iannelli, M.A., F. Pietrini, L. Fiore, L. Petrilli, and A. Massacci. 2002. Antioxidant response to cadmium in Phragmites australis plants. Plant Physiology and Biochemistry 40:977-982.
Inderjit, and S.O. Duke. 2003. Ecophysiological aspects of allelopathy. Planta 217:529-539.

Kanazawa, S., S. Sano, T. Koshiba, and T. Ushimaru. 2000. Changes in antioxidative enzymes in cucumber cotyledons during natural senescence: comparison with those during dark-induced senescence. Physiologia Plantarum 109:211-216.

Lichtenthaler, H.K. 1987. Chlorophyll and carotenoids: pigments of photosynthetic bio-membranes. p. 350-382. In Packer, L., and R. Douce (eds.) Methods in enzymology. Academic Press, San Diego, California, USA.

Liu, Y., X. Wang, G. Zeng, D. Qu, J. Gu, M. Zhou, and L. Chai. 2007. Cadmium-induced oxidative stress and response of the ascorbateglutathione cycle in Bachmeria nivea (L.) Gaud. Chemosphere 69:99-107.

Lowry, O.H., N.J. Rosebrough, A.L. Fan, and R.I. Randall. 1951. Protein measurement with the folin phenol reagent. Journal of Biological Chemistry 193:265-275.

Macias, F.A., R.M. Verela, A. Torres, J.L.G. Galindo, and J.M.G. Molinillo. 2002. Allelochemicals from sunflower: chemistry, bioactivity and application. p. 73-87. In Inderjit, and U. Mallik (eds.) Chemical ecology of plants: Allelopathy in aquatic and terrestrial ecosystem. Birkhäuser Verlag, Basel, Switzerland.

Maffei, M., C.M. Bertea, F. Garneri, and S. Scannerini. 1999. Effect of benzoic acid hydroxy- and methoxy-ring substituents during cucumber (Cucumis sativus L.) germination isocitrate lyase and catalase activity. Plant Science 141:139-147.

Metwally, A., I. Finkemeier, M. Georgi, and K.J. Dietz. 2003. Salicylic acid alleviates the cadmium toxicity in barley seedlings. Plant Physiology 132:272-281.

Middleton, E.M., and A.H. Teramura. 1993. The role of flavonol glycosides and carotenoids in protecting soybean from UV-B damage. Plant Physiology 103:741-752.

Mishra, S., and S.B. Agrawal. 2006. Interactive effects between supplemental ultraviolet-B radiation and heavy metals on the growth and biochemical characteristics of Spinacia oleracea L. Brazilian Journal of Plant Physiology 18:307-314

Mishra, S., S. Srivastava, R.D. Tripathi, R. Govindarajan, S.V. Kuriakose, and M.N.V. Prasad. 2006. Phytochelatin synthesis and response of antioxidants during cadmium stress in Bacopa monnieri L. Plant Physiology and Biochemistry 44:25-37.

Nahakpam, S., and K. Shah. 2010. Expression of key antioxidant enzymes under combined effect of heat and cadmium toxicity in growing rice seedlings. Plant Growth Regulation 63:23-35.

Nakano, Y., and K. Asada. 1981. Hydrogen peroxide is scavenged by ascorbate-specific peroxidase in spinach chloroplast. Plant and Cell Physiology 22:867-880.

Oncel, I., Y. Kele, and A.S. Ustun. 2000. Interactive effect of temperature and heavy metal stress on the growth and some biochemical compounds in wheat seedlings. Environmental Pollution 107:315-320

Oracz, K., C. Bailly, A. Gniazdowska, D. Côme, F. Corbineau, and R. Bogatek. 2007. Induction of oxidative stress by sunflower phytotoxins in germinating mustard seeds. Journal of Chemical Ecology 33:251-264.

Pacifice, R.E., and K.J.A. Davies. 1990. Protein degradation as an index of oxidative stress. Methods in Enzymology 186:485-502.

Prasad, M.N.V. 1995. Cadmium toxicity and tolerance in vascular plants. Environmental and Experimental Botany 35:525-545.

Rascio, N., F.D. Vecchia, M. Ferretti, L. Merlo, and R. Ghisi. 1993. Some effects of cadmium in maize plants. Archives of Environmental Contamination and Toxicology 25:244-249.

Roitsch, T. 1999. Source-sink regulation by sugar and stress. Current Opinion in Plant Biology 2:198-206.

Romero-Romero, T., S. Sánchez-Nieto, A. San Juan-Badillo, A.L. Anaya, and R. Cruz-Ortega. 2005. Comparative effects of allelochemical and water stress in roots of Lycopersicon esculentum Mill. (Solanaceae). Plant Science 168:1059-1066.

Shah, K., R.G. Kumar, S. Verma, and R.S. Dubey. 2001. Effect of cadmium on lipid peroxidation, superoxide anion generation and activities of antioxidant enzymes in growing rice seedlings. Plant Science 16:1135-1144. 
Sharma, S.S., S. Kaul, A. Metwally, K.C. Goyal, I. Finkemeier, and K.J. Dietz. 2004. Cadmium toxicity to barley (Hordeum vulgare) as affected by varying Fe nutritional status. Plant Science 166:1287-1295.

Singh, N.B., D. Singh, and A. Singh. 2009. Modification of physiological responses of water stressed Zea mays seedlings by leachate of Nicotiana plumbagifolia. General and Applied Plant Physiology 35:51-63.

Singh, N.B., D. Singh, and A. Singh. 2010. Allelochemicals enhance the sever effects of water stress in seedling of Phaseolus mungo. Allelopathy Journal 25:185-194.

Toppi, S.D.L., and R. Gabbrielli. 1999. Response to cadmium in higher plants. Environmental and Experimental Botany 41:105130.

Ünyayar, S., Y. Keleş, and F.Ö. Çekiç. 2005. The antioxidative response of two tomato species with different drought tolerances as a result of drought and cadmium stress combinations. Plant Soil and Environment 51:57-64.
Vaughan, D., and B.G. Ord. 1991. Extraction of potential allelochemicals and their effects on root morphology and nutrient content. p. 399-421. In D. Atkinson (ed.) Plant root growth, an ecological perspective. Blackwell Scientific, London, UK.

Wu, H.W., T. Haig, J. Partley, D. Lemerle, and M. An. 2001. Allelochemicals in wheat (Triticum aestivum L.): production and exudation of 2,4-dihydroxy-7-methoxy-1,4-benzoxazin-3-one. Journal of Chemical Ecology 27:1691-1700.

Yu, J.Q., and Y. Matusi. 1997. Effects of root exudates of cucumber (Cucumis sativus) and allelochemicals on uptake by cucumber seedlings. Journal of Chemical Ecology 23:147-151.

Zhang, E.P., S.H. Zhang, W.B. Zhang, L.L. Li, and T.L. Li. 2010. Effects of exogenic benzoic acid and cinnamic acid on the root oxidative damage of tomato seedlings. Journal of Horticulture and Forestry 2:22-29.

Zhang, P., Q. Zhou, and H. Jiang. 2007. Alleviate effects of exogenous ascorbate acid on $\mathrm{Cd}$ stress of rape seedlings. Plant Physiology 46:73-77. 